\title{
Impact of Zinc levels and sowing dates on Pearl Millet (Pennisetum glaucum L.)
}

\author{
Nihal Dwivedi $凶$ \\ Department of Agronomy, Naini Agricultural Institute , Sam Higginbottom University of Agriculture, Technology and Sciences, Prayagraj \\ Umesha C. \\ Department of Agronomy, Naini Agricultural Institute , Sam Higginbottom University of Agriculture, Technology and Sciences, Prayagraj \\ Wasim Khan \\ Department of Agronomy, Naini Agricultural Institute , Sam Higginbottom University of Agriculture, Technology and Sciences, Prayagraj
}

\begin{tabular}{|c|c|}
\hline ARTICLE INFO & ABSTRACT \\
\hline $\begin{array}{l}\text { Received : } 01 \text { June } 2021 \\
\text { Revised : } 16 \text { July } 2021 \\
\text { Accepted : } 25 \text { July } 2021 \\
\text { Available online:19 November } \\
\text { Key Words: } \\
\text { Dry weight } \\
\text { Pearl Millet } \\
\text { Plant height } \\
\text { Sowing date } \\
\text { Yield } \\
\text { Zinc }\end{array}$ & $\begin{array}{l}\text { A field experiment was conducted at Central Crop Research Farm, Department } \\
\text { of Agronomy, SHUATS, Prayagraj, (U.P.) during Zaid-2020 to study about the } \\
\text { impact of Zinc levels and sowing dates on the crop Pearl Millet. The soil of } \\
\text { experimental site was sandy loam in texture and nearly neutral in soil reaction. } \\
\text { The experiment was laid out in randomized block design and having nine } \\
\text { treatment consisted of sowing dates viz., } D_{1}\left(\text { Sowing date of April } 24^{\text {th }}\right), D_{2} \\
\left(\text { Sowing date of May } 02^{\text {nd }}\right), D_{3}\left(\text { Sowing date of May } 11^{\text {th }}\right) \text { and Zinc viz., } Z_{1}(15 \\
\mathrm{kg} / \mathrm{ha}), Z_{2}(20 \mathrm{~kg} / \mathrm{ha}), Z_{3}(25 \mathrm{~kg} / \mathrm{ha}) \text { which were replicated thrice and the impact } \\
\text { was observed on Pearl Millet crop. The result revealed that, application of Zinc } \\
\text { at } 25 \mathrm{~kg} / \mathrm{ha} \text { with the sowing date of May } 11^{\text {th }} \text { recorded significantly higher plant } \\
\text { height }(215.97 \mathrm{~cm}) \text {, Dry weight }(110.87 \mathrm{~g}) \text {, number of leaves/plant }(15.9) \text {, Test } \\
\text { weight }(7.73 \mathrm{~g}) \text {, Grain yield }(2.42 \mathrm{t} / \mathrm{ha}) \text {, Stover yield }(7.62) \text {, net returns }(₹ \\
67,293) \text { and B:C ratio }(2.84)\end{array}$ \\
\hline
\end{tabular}

\section{Introduction}

Pearl millet (Pennisetum glaucum L. ) is multipurpose cereal crop belongs to the Poaceae family. It is commonly called as Bajra, Bajri, Sajje, Kambu, Kamban, Sajjaluetc in variour Indian local languages. It is commonly used for food, feed, and forages purpose. Pearl millet, a tropical cereal and the world's most drought-resistant crop, is widely farmed throughout the world's dry and semi-arid regions (Fageria, 1992). Pearl millet is one of the most heat and drought tolerant cereals, as well as tolerant to saline and acid soils, and is easy to cultivate in dry places where rainfall is insufficient for maize or even sorghum (FAO, 2004). India produces over half of the world's pearl millet, accounting for $42 \%$ of global output (FAO, 2006). The fibre and most vitamins are low in pearl millet, although it is high in vitamin A. (NRC, 1996; DeVries and Toenniessen, 2001). Pearl millet is grown on 7.8 million hectares in India, with a yield of 9.25 million tonnes and a productivity of 1270 $\mathrm{kg}$ per hectare (Anonymous, 2016). Rajasthan,
Maharashtra, Gujarat, Uttar Pradesh, and Haryana are the primary pearl millet farming states, accounting for more than $90 \%$ of the country's pearl millet acreage (Yadav, 2011). Zinc is required for plant development and reproduction to be normal and healthy (Marschner, 1995). Grain crop panicle growth and maturity are slowed by zinc deficiency in the plant (Alloway, 2004). Zinc is a necessary component for crop production and plant development (Ali et al., 2008; Graham et al., 2001). It increases growth hormone biosynthesis, starch creation, and grain production and maturation (Brady and Weil, 2002).

Pearl millet planting time recommendations are frequently depending on the calendar day or soil temperature (Andrews et al., 1998). The delay in seeding resulted in lower results for all metrics (Iping, 1997). Yield may be boosted by identifying higher producing cultivars and planting at the right time (Khan et al., 2009 and Arif et al., 2001). The millet sowing date for direct planting has a big 
impact on how fast it grows and how much it yields (Farrell et al., 2003). Planting crops on time allows for adequate root development and vegetative growth, allowing for the most efficient use of available soil nutrients and radiant energy (Soler et al., 2008). As a result, in order to have a nice and healthy crop development, we must know when to sow Pearl millet.

Keeping these point in view, an experiment was conducted to find out the appropriate level of Zinc and date of sowing for maximizing the yield of Pearl Millet.

\section{Material and Methods}

$\mathrm{P}$ The experiment took place in the Crop Research Farm, Department of Agronomy, Sam Higginbottom University of Agriculture, Technology and Science (SHUATS), Prayagraj, during the Zaid season of 2020. (UP). The Crop Research Farm is located at 25.57 degrees north latitude, 87.19 degrees east longitude, and 98 metres above mean sea level. The experiment was set up in a randomised block design that was repeated three times. The treatment comprised of three sowing dates noted as $\mathrm{D}_{1}$ (Sowing on April 24), $D_{2}$ (Sowing on May 02) and $D_{3}$ (Sowing on May 11) and three Zinc levels $Z_{1}(15 \mathrm{~kg}$ per ha Zinc), $Z_{2}\left(20 \mathrm{~kg}\right.$ per ha Zinc), $Z_{3}(25 \mathrm{~kg}$ per ha Zinc) through surface application and the possible combinations. During the developing season, the mean week by week most extreme and least temperature, relative humidity and rainfall were $36.60{ }^{\circ} \mathrm{C}, 24.90{ }^{\circ} \mathrm{C}, 76.40 \%, 48.48 \%$ and $4.72 \mathrm{~mm}$, respectively. The Pearl millet variety 'Manipuri' was sown at a $40 \mathrm{~cm} \times 10 \mathrm{~cm}$ spacing with a seed rate of $5 \mathrm{~kg}$ per hectare. On each of the sowing dates, the field was consistently watered one day before planting. The Recommended dose of fertilizer (RDF) i.e. Nitrogen (60 kg per ha) was applied in the form of Urea in two split doses, first as basal and the remaining dose at 45 DAS(Days after sowing), whereas full dose of Phosphorous (40 kg per ha) and full dose of Potassium (40 kg per ha) were applied through DAP(Di-ammonium Phosphate) and MOP (Murate of Potash). Zinc was applied in each plot according to the treatments before sowing of seed along with fertilizers during first split as basal. The recorded data were analysed statistically by ANOVA technique (Gomez and Gomez, 1984). Significant difference among the treatment mean was verified against the critical difference at five per cent level of significance. Relative economics was calculated as per the prevailing market prices of the inputs and produced during Zaid season.

\section{Results and Discussion \\ Plant height}

At 15 DAS, maximum plant height was recorded with application of $15 \mathrm{~kg} / \mathrm{ha}$ Zinc with the sowing date of May $2^{\text {nd }}(5.13 \mathrm{~cm})$, there is no significant variance among the all the treatments. At $30 \mathrm{DAS}$, maximum plant height was recorded with application of $25 \mathrm{~kg} / \mathrm{ha}$ Zinc with the sowing date of April $24^{\text {th }}(10.23 \mathrm{~cm})$, there is no significant variance among the all the treatments. At 45 DAS, maximum plant height was recorded with application of $25 \mathrm{~kg} / \mathrm{ha}$ Zinc with the sowing date of May $11^{\text {th }}(66.39 \mathrm{~cm})$, which was considerably superior over all the treatments except $25 \mathrm{~kg} / \mathrm{ha}$ Zinc with the sowing date of April $24^{\text {th }}$. At 60 DAS, maximum plant height was recorded with application of $25 \mathrm{~kg} / \mathrm{ha}$ Zinc with the sowing date of May $11^{\text {th }}(122.93 \mathrm{~cm})$, which was considerably superior over all the treatments except $25 \mathrm{~kg} / \mathrm{ha}$ Zinc with each the sowing date April $24^{\text {th }}$ and May $2^{\text {nd }}$ (Table 1). At 75 DAS, the greatest plant height was obtained with a $25 \mathrm{~kg} /$ ha Zinc application and a sowing date of May 11th $(163.10 \mathrm{~cm})$, which was considerably superior to all other treatments except $25 \mathrm{~kg} / \mathrm{ha}$ Zinc with each of the sowing dates April $24^{\text {th }}$ and May $2^{\text {nd }}$. At harvest, maximum plant height was recorded with application of $25 \mathrm{~kg} / \mathrm{ha}$ Zinc with the sowing date of May $11^{\text {th }}(215.97 \mathrm{~cm})$, which was considerably superior over all the treatments except $25 \mathrm{~kg} / \mathrm{ha}$ Zinc with the sowing date of May $2^{\text {nd }}$. Since Zinc is involved in the biosynthesis of Indole acetic acid (IAA), a growth hormone, involved in stem elongation, hence the increase in the plant height. Increase in plant height with sowing date of May $11^{\text {th }}$ might have represented congenial weather conditions like prolonged photoperiod, optimum temperatures and sufficient amount of moisture levels at vegetative growth. Similar results were also observed by Prasad et al. (2014).

\section{Dry weight}

At 15 DAS, maximum dry weight was recorded with application of $15 \mathrm{~kg} / \mathrm{ha}$ Zinc with the sowing date of May $2^{\text {nd }}(0.17 \mathrm{~g})$, there is no significant 
Table 1 : Effect of Zinc levels and sowing dates on Plant height $(\mathrm{cm})$ of Pearl millet

\begin{tabular}{|c|c|c|c|c|c|c|}
\hline Treatment combination & 15 DAS & 30 DAS & 45 DAS & 60 DAS & 75 DAS & At harvest \\
\hline $\begin{array}{l}\mathrm{T}_{1} \text { : Sowing on April } 24+15 \mathrm{~kg} / \mathrm{ha} \mathrm{Zn} \\
(\text { Control) }\end{array}$ & 4.80 & 8.07 & 47.40 & 105.23 & 148.37 & 195.03 \\
\hline $\mathrm{T}_{2}$ : Sowing on April $24+20 \mathrm{~kg} / \mathrm{ha} \mathrm{Zn}$ & 4.73 & 9.07 & 51.87 & 110.97 & 152.37 & 201.50 \\
\hline $\mathrm{T}_{3}$ : Sowing on April $24+25 \mathrm{~kg} / \mathrm{ha} \mathrm{Zn}$ & 4.92 & 10.23 & 60.95 & 117.90 & 160.20 & 207.13 \\
\hline $\mathrm{T}_{4}$ : Sowing on May $2+15 \mathrm{~kg} / \mathrm{ha} \mathrm{Zn}$ & 5.13 & 7.73 & 46.40 & 102.77 & 147.87 & 192.70 \\
\hline $\mathrm{T}_{5}$ : Sowing on May $2+20 \mathrm{~kg} / \mathrm{ha} \mathrm{Zn}$ & 4.93 & 8.03 & 51.37 & 111.33 & 153.03 & 201.20 \\
\hline $\mathrm{T}_{6}$ : Sowing on May $2+25 \mathrm{~kg} / \mathrm{ha} \mathrm{Zn}$ & 4.84 & 9.03 & 59.40 & 120.10 & 160.33 & 214.53 \\
\hline $\mathrm{T}_{7}$ : Sowing on May $11+15 \mathrm{~kg} / \mathrm{ha} \mathrm{Zn}$ & 4.80 & 7.60 & 48.80 & 105.70 & 149.00 & 196.37 \\
\hline $\mathrm{T}_{8}$ : Sowing on May $11+20 \mathrm{~kg} / \mathrm{ha} \mathrm{Zn}$ & 4.69 & 8.33 & 53.80 & 111.53 & 154.53 & 205.60 \\
\hline $\mathrm{T}_{9}$ : Sowing on May $11+25 \mathrm{~kg} / \mathrm{ha} \mathrm{Zn}$ & 4.69 & 9.83 & 66.39 & 122.93 & 163.10 & 215.97 \\
\hline F-test & NS & NS & $\mathrm{S}$ & $\mathrm{S}$ & $\mathrm{S}$ & $\mathrm{S}$ \\
\hline S.Ed. $( \pm)$ & 1.9930 & 0.8721 & 2.5819 & 2.5632 & 1.54 & 2.7905 \\
\hline $\mathrm{CD}$ at $5 \%$ & - & - & 5.46 & 5.43 & 3.26 & 5.91 \\
\hline
\end{tabular}

Table 2: Effect of Zinc levels and sowing dates on Dry weight(g) of Pearl millet

\begin{tabular}{|c|c|c|c|c|c|c|}
\hline Treatment combination & 15 DAS & 30 DAS & 45 DAS & 60 DAS & 75 DAS & At harvest \\
\hline $\mathrm{T}_{1}$ : Sowing on April $24+15 \mathrm{~kg} / \mathrm{ha} \mathrm{Zn}$ (Control) & 0.14 & 2.85 & 24.53 & 60.43 & 84.50 & 90.40 \\
\hline $\mathrm{T}_{2}$ : Sowing on April $24+20 \mathrm{~kg} / \mathrm{ha} \mathrm{Zn}$ & 0.16 & 3.28 & 26.87 & 62.17 & 86.57 & 95.83 \\
\hline $\mathrm{T}_{3}$ : Sowing on April $24+25 \mathrm{~kg} / \mathrm{ha} \mathrm{Zn}$ & 0.12 & 3.39 & 28.37 & 64.90 & 91.43 & 105.77 \\
\hline $\mathrm{T}_{4}$ : Sowing on May $2+15 \mathrm{~kg} / \mathrm{ha} \mathrm{Zn}$ & 0.17 & 2.75 & 23.80 & 55.40 & 82.63 & 91.40 \\
\hline $\mathrm{T}_{5}$ : Sowing on May $2+20 \mathrm{~kg} / \mathrm{ha} \mathrm{Zn}$ & 0.12 & 2.77 & 23.43 & 62.33 & 83.83 & 95.07 \\
\hline $\mathrm{T}_{6}$ : Sowing on May $2+25 \mathrm{~kg} / \mathrm{ha} \mathrm{Zn}$ & 0.14 & 3.28 & 28.33 & 64.07 & 90.80 & 104.23 \\
\hline $\mathrm{T}_{7}$ : Sowing on May $11+15 \mathrm{~kg} / \mathrm{ha} \mathrm{Zn}$ & 0.14 & 2.99 & 21.30 & 60.77 & 82.40 & 93.60 \\
\hline $\mathrm{T}_{8}$ : Sowing on May $11+20 \mathrm{~kg} / \mathrm{ha} \mathrm{Zn}$ & 0.14 & 2.87 & 23.23 & 61.13 & 88.30 & 100.37 \\
\hline $\mathrm{T}_{9}$ : Sowing on May $11+25 \mathrm{~kg} / \mathrm{ha} \mathrm{Zn}$ & 0.14 & 3.25 & 29.30 & 65.37 & 93.60 & 110.87 \\
\hline F-test & NS & NS & $\mathrm{S}$ & $\mathrm{S}$ & $\mathrm{S}$ & $\mathrm{S}$ \\
\hline S.Ed. $( \pm)$ & 0.01 & 0.34 & 1.51 & 1.98 & 1.56 & 1.46 \\
\hline $\mathrm{CD}$ at $5 \%$ & - & - & 3.20 & 4.21 & 3.31 & 3.10 \\
\hline
\end{tabular}


variance among the all the treatments. At 30 DAS, maximum dry weight was recorded with application of $25 \mathrm{~kg} / \mathrm{ha}$ Zinc with the sowing date of April $24^{\text {th }}(3.39 \mathrm{~g})$, there is no significant variance among the all the treatments. At 45 DAS, maximum dry weight was recorded with application of $25 \mathrm{~kg} / \mathrm{ha}$ Zinc with the sowing date of May $11^{\text {th }}(29.30 \mathrm{~g})$, which was considerably superior over all the treatments except $20 \mathrm{~kg} / \mathrm{ha}, 25$ $\mathrm{kg} / \mathrm{ha}$ Zinc with the sowing date of April $24^{\text {th }}$ and $25 \mathrm{~kg} / \mathrm{ha}$ Zinc with the sowing date of May $2^{\text {nd }}$. At 60 DAS, maximum dry weight was recorded with application of $25 \mathrm{~kg} / \mathrm{ha}$ Zinc with the sowing date of May $11^{\text {th }}(65.37 \mathrm{~g})$, which was considerably superior over all the treatments except $20 \mathrm{~kg} / \mathrm{ha}, 25$ $\mathrm{kg} / \mathrm{ha}$ Zinc with the sowing date April $24^{\text {th }}$ and May $2^{\text {nd }}$ each and $20 \mathrm{~kg} / \mathrm{ha}$ Zinc with the sowing date of May $11^{\text {th }}$ (Table 2). At 75 DAS, maximum dry weight was recorded with application of $25 \mathrm{~kg} / \mathrm{ha}$ Zinc with the sowing date of May $11^{\text {th }}(93.60 \mathrm{~g})$, which was considerably superior over all the treatments except $25 \mathrm{~kg} / \mathrm{ha}$ Zinc with each of the sowing date April $24^{\text {th }}$ and May $2^{\text {nd }}$. At harvest, maximum dry weight was recorded with application of $25 \mathrm{~kg} / \mathrm{ha}$ Zinc with the sowing date of May $11^{\text {th }}(110.87 \mathrm{~g})$, which was significantly superior over all the treatments. The significant increase in dry matter yield may be attributed to the higher photosynthetic rate. Zinc is a constituent of carbonic anhydrase (An enzyme promotes carbon dioxide assimilation pathway in $\mathrm{C}_{4}$ cycle of photosynthesis) and there is direct relationship between carbonic anhydrase activity and photosynthetic carbon dioxide assimilation on growth of a plants. Carbonic anhydrase activity is closely related to Zinc content as such Zinc increases photosynthetic efficiency and thereby dry matter production. Similar results were observed by Andhale et al. (2007), Upadhyay et al. (2001), Jain et al. (2001), and Jakhar et al. (2006).

\section{Number of leaves per plant}

At 30 DAS, maximum number of leaves/plant was recorded with application of $25 \mathrm{~kg} / \mathrm{ha}$ Zinc with the sowing date of May $11^{\text {th }}$ (12.78), there is no significant variance among all the treatments. At 45 DAS, maximum number of leaves/plant was recorded with application of $25 \mathrm{~kg} / \mathrm{ha}$ Zinc with the sowing date of May $11^{\text {th }}$ (15.48), which was significantly superior among the all the treatments except $25 \mathrm{~kg} / \mathrm{ha}$ with the sowing date of April $24^{\text {th }}$ and May $2^{\text {nd }}$. At 60 DAS, maximum number of leaves/plant was recorded with application of 25 $\mathrm{kg} / \mathrm{ha}$ Zinc with the sowing date of May $11^{\text {th }}(18)$, which was considerably superior over all the treatments except $20 \mathrm{~kg} / \mathrm{ha}, 25 \mathrm{~kg} / \mathrm{ha} Z$ Zinc with the sowing date April $24^{\text {th }}$ and May $2^{\text {nd }}$ each and 20 $\mathrm{kg} / \mathrm{ha}$ Zinc with the sowing date of May $11^{\text {th }}$ (Table 3). At 75 DAS, maximum number of leaves/plant was recorded with application of $25 \mathrm{~kg} / \mathrm{ha}$ Zinc with the sowing date of May $11^{\text {th }}(17.1)$, which was considerably superior over all the treatments except $20 \mathrm{~kg} / \mathrm{ha}, 25 \mathrm{~kg} / \mathrm{ha}$ Zinc with each of the sowing date April $24^{\text {th }}$ and May $2^{\text {nd }}$ and $20 \mathrm{~kg} /$ ha Zinc with the sowing date of May $11^{\text {th }}$. At harvest, maximum number of leaves/plant was recorded with application of $25 \mathrm{~kg} / \mathrm{ha}$ Zinc with the sowing date of May $11^{\text {th }}(15.9)$, which was considerably superior over all the treatments except $20 \mathrm{~kg} / \mathrm{ha}, 25$ $\mathrm{kg} / \mathrm{ha}$ Zinc with the sowing date April $24^{\text {th }}$ and May $2^{\text {nd }}$ each and $20 \mathrm{~kg} / \mathrm{ha}$ Zinc with the sowing date of May $11^{\text {th }}$. Zinc treatment may have influenced the leaf count, which grew with crop age and peaked at 60 DAS due to a consistent supply of nutrients, moisture, and light, before declining. This might be due to ageing, death, or leaf drying. The increase in growth parameters of Pearl millets due to application of Zinc have also been reported by Dhaka (1984), and Maliwal et. at. (1985) and Singh (1989).

\section{Effect on yield attributes and yield}

Application of $25 \mathrm{~kg} / \mathrm{ha}$ Zinc with the sowing date of May $11^{\text {th }}$, recorded maximum test weight (7.73 g), which was significantly superior to all the treatments except $25 \mathrm{~kg} / \mathrm{ha}$ Zinc with each of the sowing date April $24^{\text {th }}$ and May $2^{\text {nd }}$ (Table 4). Also the application of $25 \mathrm{~kg} / \mathrm{ha}$ Zinc with the sowing date of May $11^{\text {th }}$, recorded maximum grain yield (2.42 t/ha), which was significantly superior to all the treatments except $25 \mathrm{~kg} / \mathrm{ha}$ Zinc with each of the sowing date April $24^{\text {th }}$ and May $2^{\text {nd }}$ and 20 $\mathrm{kg} / \mathrm{ha}$ with the sowing date May $11^{\text {th }}$. Application of $25 \mathrm{~kg} / \mathrm{ha}$ Zinc with the sowing date of May $11^{\text {th }}$, recorded maximum Stover yield (7.62 t/ha), which was significantly superior to all the treatments. Zinc improved the yield and yield attributes by improving the source and sink relation due to increased translocation of photosynthates towards reproductive system. The results are in agreement with those of Jan et al. (2015), Maurya et al. (2016). 
Table 3: Effect of Zinc levels and sowing dates on Number of leaves/plant of Pearl millet

\begin{tabular}{|c|c|c|c|c|c|}
\hline Treatment combination & 30 DAS & 45 DAS & 60 DAS & 75 DAS & At harvest \\
\hline $\mathrm{T}_{1}$ : Sowing on April $24+15 \mathrm{~kg} / \mathrm{ha} \mathrm{Zn}$ (Control) & 12.17 & 13.21 & 14.7 & 13.8 & 12.5 \\
\hline $\mathrm{T}_{2}$ : Sowing on April $24+20 \mathrm{~kg} / \mathrm{ha} \mathrm{Zn}$ & 12.41 & 14.19 & 16.4 & 15.3 & 14.2 \\
\hline $\mathrm{T}_{3}$ : Sowing on April $24+25 \mathrm{~kg} / \mathrm{ha} \mathrm{Zn}$ & 12.64 & 15.07 & 17.3 & 16.4 & 15.1 \\
\hline $\mathrm{T}_{4}$ : Sowing on May $2+15 \mathrm{~kg} / \mathrm{ha} \mathrm{Zn}$ & 12.22 & 13.29 & 14.2 & 13.3 & 12.0 \\
\hline $\mathrm{T}_{5}$ : Sowing on May $2+20 \mathrm{~kg} / \mathrm{ha} \mathrm{Zn}$ & 12.34 & 14.81 & 16.8 & 15.5 & 14.1 \\
\hline $\mathrm{T}_{6}$ : Sowing on May $2+25 \mathrm{~kg} / \mathrm{ha} \mathrm{Zn}$ & 12.54 & 15.08 & 17.5 & 16.2 & 15.0 \\
\hline $\mathrm{T}_{7}$ : Sowing on May $11+15 \mathrm{~kg} / \mathrm{ha} \mathrm{Zn}$ & 12.29 & 13.09 & 14.2 & 13.0 & 11.9 \\
\hline $\mathrm{T}_{8}$ : Sowing on May $11+20 \mathrm{~kg} / \mathrm{ha} \mathrm{Zn}$ & 12.42 & 14.68 & 16.5 & 15.4 & 14.5 \\
\hline $\mathrm{T}_{9}$ : Sowing on May $11+25 \mathrm{~kg} / \mathrm{ha} \mathrm{Zn}$ & 12.78 & 15.48 & 18.0 & 17.1 & 15.9 \\
\hline F-test & NS & $\mathrm{S}$ & $\mathrm{S}$ & $\mathrm{S}$ & $\mathrm{S}$ \\
\hline S.Ed. $( \pm)$ & 0.54 & 0.26 & 1.04 & 0.90 & 0.86 \\
\hline CD at $5 \%$ & -- & 0.56 & 2.02 & 1.90 & 1.83 \\
\hline
\end{tabular}

Table 4: Effect of Zinc levels and sowing dates on yield attributes, yield and economics of Pearl millet

\begin{tabular}{|c|c|c|c|c|c|}
\hline Treatment & $\begin{array}{l}\text { Test } \\
\text { weight (g) }\end{array}$ & $\begin{array}{c}\text { Grain yield } \\
(\mathrm{t} / \mathrm{ha})\end{array}$ & $\begin{array}{l}\text { Stover yield } \\
\text { (t/ha) }\end{array}$ & $\begin{array}{l}\text { Net returns } \\
\text { (INR/ha) }\end{array}$ & $\begin{array}{l}\mathrm{B}: \mathrm{C} \\
\text { ratio }\end{array}$ \\
\hline $\begin{array}{l}\mathrm{T}_{1} \text { : Sowing on April } 24+15 \mathrm{~kg} / \mathrm{ha} \mathrm{Zn} \\
\text { (Control) }\end{array}$ & 6.50 & 1.56 & 6.04 & 40,123 & 1.74 \\
\hline $\mathrm{T}_{2}$ : Sowing on April $24+20 \mathrm{~kg} / \mathrm{ha} \mathrm{Zn}$ & 7.12 & 1.82 & 6.46 & 47,978 & 2.05 \\
\hline $\mathrm{T}_{3}$ : Sowing on April $24+25 \mathrm{~kg} / \mathrm{ha} \mathrm{Zn}$ & 7.48 & 2.25 & 7.24 & 61,523 & 2.59 \\
\hline $\mathrm{T}_{4}$ : Sowing on May $2+15 \mathrm{~kg} / \mathrm{ha} \mathrm{Zn}$ & 6.62 & 1.50 & 6.09 & 38,823 & 1.68 \\
\hline $\mathrm{T}_{5}$ : Sowing on May $2+20 \mathrm{~kg} / \mathrm{ha} \mathrm{Zn}$ & 7.29 & 1.93 & 6.49 & 50,848 & 2.17 \\
\hline $\mathrm{T}_{6}$ : Sowing on May $2+25 \mathrm{~kg} / \mathrm{ha} \mathrm{Zn}$ & 7.56 & 2.28 & 7.27 & 62,393 & 2.63 \\
\hline $\mathrm{T}_{7}$ : Sowing on May $11+15 \mathrm{~kg} / \mathrm{ha} \mathrm{Zn}$ & 6.67 & 1.62 & 6.14 & 42,023 & 1.82 \\
\hline $\mathrm{T}_{8}$ : Sowing on May $11+20 \mathrm{~kg} / \mathrm{ha} \mathrm{Zn}$ & 7.06 & 2.06 & 6.61 & 54,578 & 2.33 \\
\hline $\mathrm{T}_{9}$ : Sowing on May $11+25 \mathrm{~kg} / \mathrm{ha} \mathrm{Zn}$ & 7.73 & 2.42 & 7.62 & 67,293 & 2.84 \\
\hline
\end{tabular}

\section{Economics}

Higher Net return (INR 67,293) and B:C ratio (2.84) was obtained with the application of 25 $\mathrm{kg} / \mathrm{ha}$ Zinc with the sowing date of May $11^{\text {th }}$ (Table 4). Higher Net return in the given treatment was primarily due to higher seed and Stover yields obtained from Pearl millet.

\section{Conclusion}

Pearl Millet is generally a Kharif season crop but can also be grown during Zaid season as it consumes less water than the other cereal crops. So, for obtaining higher yield in Pearl millet during the

\section{References}

Ali, S., Khan, A. R., Mairaj, G., Arif, M., Fida, M., \& Bibi, S. (2008). Assessment of different crop nutrient management practices for yield improvement. Australian Journal of Crop Science, 2(3), 150-157. late Zaid season, application of $25 \mathrm{~kg} / \mathrm{ha}$ Zinc can be more beneficial than $15 \mathrm{~kg} / \mathrm{ha}$ or $20 \mathrm{~kg} / \mathrm{ha}$ Zinc. While in case of sowing date, mid-May period could provide more congenial weather condition (warm and humid i.e. better utilization of minerals and nutrients) to the Pearl millet crop than late April or May starting period.

\section{Acknowledgement}

I express gratitude to my advisor Dr. Umesha C. and all the faculty members of Department of Agronomy for constant support and guidance to carry out the whole experimental research study.

Alloway, B. J. (2004). Zinc in soils and crop nutrition. International Zinc Association Communications. Brussels: IZA Publications.

Andrews, D. J., Rajewski, J. F., \& Mason, S. C. (1998). Grain pearl millet: a new crop being developed at UNL. Ext. Visions, 2(1), 2-6. 
Anonymous (2016). Project Coordinator Review on Pearl Millet Research. AICPMP Workshop, Jodhpur. pp 3.

Arif, M., Khan, S., Ghani, F., \& Yousafzai, H. K. (2001). Response of maize varieties to different planting methods. Sarhad Journal of Agriculture (Pakistan).

Brady, N. C., \& Weil, R. R. (2002). The nature and properties of soils, 13th addition.

DeVries, J., \& Toenniessen, G. H. (2001). Securing the harvest: biotechnology, breeding, and seed systems for African crops. CABI.

Dhaka, S.S. (1984). Studies on the effect of Phosphate, Zinc and FYM fertilization on pearl millet production. M.Sc. (Ag.) Thesis, Sukhadia University, Udaipur.

Fageria, N.K. (1992). Maximizing crop yields. New York: Marcel Dekker.

FAO (2004). Pennesitum americanum (L.) Leeke: species description. Food and Agriculture Organization of the United Nations, Rome.

FAO (2006). The state of Food Insecurity in the World. FAO, Rome.

Farrell, T. C., Fox, K., Williams, R. L., Fukai, S. \& Lewin, L. G. (2003). Avoiding low temperature damage in Australia's millet industry with photoperiod sensitive cultivars. Proceedings of the Australian Agronomy Conference, Australian Society of Agronomy.

Gomez, K. A., \& Gomez, A. A. (1984). Statistical procedures for agricultural research. John Wiley \& Sons.

Graham, R. D., Welch, R. M., \& Bouis, H. E. (2001). Addressing micronutrient malnutrition through enhancing the nutritional quality of staple foods: principles, perspectives and knowledge gaps.

Iping, S. A. (1997). The effects of dates of planting on yield and yield components of pearl millet. Ministry for Agriculture, Water and Rural Development, Private Bag, 13184.

Jain, N. K., Poonia, B. L., \& Singh, R. P. (2001). Response of pearl millet (Pennisetunl glaucum) to zinc fertilization in flood-prone eastern plains zone of Rajasthan. The Indian Journal of Agricultural Sciences, 71(5).
Jakhar, S. R., Singh, M. \& Balai, C. M. (2006). Effect of farmyard manure, phosphorus and Zinc levels on growth, yield, quality and economics of Pearl millet (Pennisetum glaucum). Indian Journal of Agricultural Sciences, 76 (1), $58-61$.

Jan, A., Khan, I., \& Sohail, S. A. A. A. (2015). Sowing dates and sowing methods influenced on growth yield and yield components of pearl millet under rainfied conditions. Journal of Environment and Earth Science, 5(1), 105-109.

Khan, Z. H., Khalil, S. K., Nigar, S., Khalil, I., Haq, I., Ahmad, I., ... \& Khan, M. Y. (2009). Phenology and yield of sweet corn landraces influenced by planting dates. Sarhad J. Agric, 25(2), 153-157.

Marschner, H. (1995). Mineral nutrition of high plant. Academic Press, 330-355.

Maurya, S.K., Nath, S., Patra, S.S. \& Rout, S. (2016). Effect of different dates on growth and yield of Pearl millet (Pennisetum glaucum L.) Indian J. S. N. 7(1), 62-69.

NRC, (1996). Lost crops of Africa, grains. National Research Council/National Academy Press, Washington, D.C. vol 1.

Prasad S.K., Singh, M.K. \& Singh, R. (2014). Effect of Nitrogen and Zinc on growth, yield and uptake of Pearl millet (Pennisetum glaucum L.). An Inter. Quarterly J. Life Sci., 9(1),163-166.

Singh, B.P. (1989). Balanced fertilization is the key for higher yield of pearl millet. Haryana Farming. 28 (8), 5-6.

Soler, C. M. T., Maman, N., Zhang, X., Mason, S. C., \& Hoogenboom, G. (2008). Determining optimum planting dates for pearl millet for two contrasting environments using a modelling approach. The Journal of Agricultural Science, 146(4), 445-459.

Upadhyay, P. N., Dixit, A. G., Patel, J. R., \& Chavda, J. R. (2001). Response of summer pearlmillet (Pennisetum glaucum) to time and method of planting, age of seedling and phosphorus grown on loamy sand soils of Gujarat. Indian Journal of Agronomy, 46(1), 126-130.

Yadav, O.P. (2011). All India Coordinated Pearl Millet Improvement Project, Jodhpur, Rajasthan, India AICPMIP Workshop, Hisar, 342:304. 